\title{
GENETIC STUDIES ON SOME QUANTITATIVE TRAITS IN PEA 1. INHERITANCE OF VEGETATIVE CHARACTERS, YIELD AND ITS COMPONENTS
}

\author{
HAMED, A. A., A. H. HUSSEIN and E. M. E. A. KHALIL
}

Veg. Res. Dept., Horticulture Res. Inst., ARC, Giza, Egypt.

(Manuscript received 5 July 2015)

\begin{abstract}
$\mathrm{T}$ his study was conducted in Horticulture Research Institute during the period from 2012 to 2015 to study the inheritance of some garden pea economic characters, viz., plant length, number of branches/plant, green pod yield/plant, number of pods/plant and pod weight. Four garden pea cvs., viz, Master, Perfection 57, Prism and Twin were chosen to produce 3 crosses and their reciprocals. Results showed that maternal effect was absence in all studied characters. Over dominance was detected for high number of branches/plant, high green pod yield/plant and high number of pods/plant in all studied crosses. Over dominance or complete dominance was detected for high plant length. High pod weight was dominant in some studied crosses and the opposite was found in the others. Positive heterosis over the better parent was found in all studied crosses for plant length, number of branches/plant, green pod yield/plant and number of pods/plant traits, however, negative heterosis was detected in all studied crosses for pod weight. Minimum number of estimated genes was one for plant length trait, 1-9 for number of branches/plant, 2-3 for green yield/plant, 3-6 for number of pods/plant and pod weight. Broad sense heritability estimates were $79.49 \%-89.65 \%$ for plant length, $75.14 \%-83.69 \%$ for number of branches/plant, $79.44 \%-90.81 \%$ for green yield/plant, $77.30 \%$ $79.91 \%$ for number of pods/plant, while it was $30.75 \%-53.43 \%$ for pod weight.

Key words: Pisum sativum, Dominance, Heterosis, Number of genes, Heritability, Plant length, Green yield, Yield components.
\end{abstract}

\section{INTRODUCTION}

Garden pea, Pisum sativum L., is a short cash vegetable crop during winter season in Egypt. The improvement of pea yield depends upon a better understanding of the type of gene action controlling yield and its attributed components. Recently there are intensive efforts for improvement of pea productivity in Egypt through breeding procedures depending mainly on the presence of genetic differences that permits effective selection. Hybridization is considered main effective factor for inducing variability.

Non-significant differences were observed between $F_{1}$ 's and their reciprocals in peas for plant length trait in all studied crosses indicating absence of maternal 
effect (Noser, 2002 and Hamed, 2005). Noser (2002), Hamed (2005) and Sood and Kalia (2006) found that dominance of plant length was variable according to the parental lines used. Heterosis over the taller parent ranged from $0.98 \%$ to $83.28 \%$ as estimated by Noser (2002). Meanwhile, Hamed (2005) found negative heterosis in some pea crosses and positive heterosis in others. Noser (2002) found that plant length of peas was governed by 1-5 genes, while, Hamed (2005) estimated it as 1-3 pairs of genes. Broad sense heritability (BSH) of plant length of pea was high in the broad sense (Bora et al., 2009, Kumari et al., 2009 and Galal, 2014) which suggested that this trait would respond to selection. Also, Noser (2002), Hamed (2005) and Zayed et al. (2005) estimated BSH as from $16.19 \%$ to $76.60 \%$, from $54.6 \%$ to $74.2 \%$, and $96.6 \%$, respectively.

No-significant differences were obtained between $F_{1}$ 's and their reciprocals for number of branches/plant trait in all studied crosses indicating absence of maternal effect (Noser, 2002). Presence of over dominance and complete dominance towards the highest parent for this trait was indicated by Noser (2002) and Singh and Mishra (2002) on pea. All the studied crosses exhibited positive heterosis over better parent ranging from $13.59 \%$ to $36.59 \%$ (Noser, 2002). Minimum number of genes (MNG) controlling number of branches/plant trait was estimated as 1-3 pairs (Noser, 2002), while, Singh and Mishra (2002) estimated it as one pair of genes. Gupta et al. (2006) and Singh (2010) on pea estimated high values of heritability in the broad sense for this trait, meanwhile, El-Dakkak et al. (2014) found moderate to high heritability for this trait.

Maternal effect was remarked for green pod yield/plant trait only in 2 out of 6 crosses of garden peas (Noser, 2002). High positive $P$ values indicated over dominance and partial dominance towards the high yielding parent were estimated (Sood and Kalia, 2006). Meanwhile, Noser (2002) found different types of dominance for this trait. Noser (2002) observed significant positive heterosis of pod green yield/plant in all studied crosses estimating as $6.54 \%$ to $74.93 \%$ except in one cross which exhibited negative heterosis. Minimum number of genes controlling green pod yield/plant trait was estimated as a single pair of genes in all crosses (Noser, 2002). High BSH estimates were observed for green pod yield trait (Bora et al., 2009, Choudhary et al., 2010, Singh, 2010 and El-Dakkak et al., 2014). Zayed et al. (2005) estimated BSH as $66.4 \%$.

Noser (2002) indicated that maternal effect was not observed for number of pods/plant trait in any of the studied crosses. Meanwhile, Hamed (2005) found that maternal effect existed for this trait only in one out of the four studied crosses. Over dominance for number of pods per plant was reported by Sood and Kalia (2006). 
Noser (2002) found over dominance of the highest parent in three crosses and complete dominance of the highest parent in three others. Hamed (2005) observed complete dominance of the highest parent in 3 out of 4 crosses and complete dominance of the lowest number of pods/plant in one cross. Positive heterosis over the better parent for this trait ranged from $6.44 \%$ to $104.21 \%$ (Noser, 2002). On the contrary, Hamed (2005) estimated negative heterosis values ranged from $-32.7 \%$ to $2.9 \%$ in all evaluated crosses. Minimum number of genes controlling number of pods/plant was one pair of genes in all studied crosses (Noser, 2002 and Singh and Mishra, 2002). Meanwhile, Hamed (2005) estimated it as 1-7 pairs of genes. Kumari et al. (2009), Choudhary et al. (2010) and Singh et al. (2012) estimated high values of heritability in the broad sense indicating good scope for selection for number of pods/plant trait. In the same direction, Galal (2014) on pea estimated BSH for number of pods/plant trait as $90.0 \%-91.5 \%$. While, it was moderate to high and ranged from $54.9 \%$ to $86.0 \%$, from $37.9 \%$ to $78.8 \%, 86.6 \%$ and from $32.12 \%$ to $86.61 \%$ as estimated by Noser (2002), Hamed (2005), Zayed et al. (2005) and El-Dakkak et al. (2014), respectively.

Non-significant differences were observed between $F_{1}$ 's and their reciprocals for pod weight character indicating no maternal effect (Hamed, 2005). Hamed (2005) found partial dominance towards the lowest parent for this character. Negative heterosis values for this trait were estimated as $-24.0 \%$ to $-26.9 \%$ (Hamed, 2005). Minimum number of genes controlling pod weight was estimated as 3-5 pairs (Hamed, 2005). High estimates of BSH were obtained for pod weight by Bora et al. (2009), meanwhile, Gupta et al. (2006) and Galal (2014) estimated it as 74.65 and $75.0 \%$ to $80.0 \%$, respectively. On the contrary, Hamed (2005) found low BSH being $17.6 \%$ to $22.6 \%$ for this trait.

The main objective of the present investigation was to study the inheritance of some economic characters of garden pea to produce and select new lines with high yielding ability which can be included in subsequent breeding programs.

\section{MATERIALS AND METHODS}

This study was conducted during the period from 2012 to 2015. Production and evaluation of genetic populations were carried out in the open field at Kaha Vegetable Research Farm, Kalubia Governorate, Egypt. Four garden pea cvs., viz, Master, Perfection 57, Prism and Twin were chosen for genetic studies based on their performance as shown in Table 1. 
Table 1. Description of studied cultivars.

\begin{tabular}{|l|c|c|c|c|c|c|c|}
\hline Cultivar & $\begin{array}{c}\text { Stem } \\
\text { length }\end{array}$ & Leaf type & $\begin{array}{c}\text { No. of } \\
\text { days from } \\
\text { sowing to } \\
\text { flowering }\end{array}$ & $\begin{array}{c}\text { No. of } \\
\text { nods } \\
\text { to first } \\
\text { pod }\end{array}$ & $\begin{array}{c}\text { No. of } \\
\text { pods/node }\end{array}$ & Pod color & $\begin{array}{c}\text { Seed } \\
\text { size }\end{array}$ \\
\hline Master & Short & Conventional & 44 & $7-8$ & $1-2$ & Green & Medium \\
\hline Perfection 57 & Medium & Leafless & 55 & $13-14$ & $2-3$ & Green & Medium \\
\hline Prism & Short & Leafless & 60 & $13-14$ & 2 & Dark green & Medium \\
\hline Twin & Medium & Conventional & 60 & $13-14$ & $2-3$ & Green & Small \\
\hline
\end{tabular}

Seeds of these cultivars were sown in the open field at Kaha on mid October, 2012. Three crosses, viz., Master $\times$ Perfection 57 , Master $\times$ Prism and Master $\times$ Twin and their reciprocals were produced. Seeds of the straight $F_{1}$ crosses were sown on mid October, 2013. Flowers on plants were left for selfing to produce $F_{2}$ seeds. In the same time, production of $F_{1}$ seeds was completed.

Evaluation of genetic populations was carried out at Kaha. Seeds of parents, $F_{1}$, $F_{1} r$ and $F_{2}$ populations of each of the three crosses were sown on mid October, 2014 in a randomized complete block design with three replicates. Each replicate consisted of one row for every non-segregating population, i.e., parents, $F_{1}$ and their reciprocals and three rows for each $F_{2}$. Each row was $3.0 \mathrm{~m}$ long and $0.7 \mathrm{~m}$ wide. Individual seeds were sown $15 \mathrm{~cm}$ apart. Cultural practices such as irrigation, chemical fertilization and disease and insect control were practiced as commonly followed in this district.

Data were recorded on individual plants for the different populations in each cross for plant length, number of branches/plant, green pod yield/plant, number of pods/plant and pod weight. Characters were studied only in the crosses which their parents were significantly different in such characters.

Data were recorded as follow:

Plant length was measured at the end of the harvesting season from the surface of the soil to the highest point of the stem in $\mathrm{cm}$. Number of branches/plant was measured as the main branches/plant. Green pod yield/plant was measured as the weight of all harvested pods. Number of pods/plant. Pod weight was estimated as the mean of five pods/plant in $\mathrm{g}$.

\section{Genetic parameters estimated}

Maternal effect was estimated by measuring the significance of difference between each $F_{1}$ mean and it's reciprocal by the ( $t$ ) test.

Potence ratio, i.e., the relative potency of gene set $(P)$ was used to determine the direction of dominance according to the following formula (Smith, 1952):

$$
P=\frac{\overline{F_{1}}-M P}{1 / 2\left(\overline{P_{2}}-\overline{P_{1}}\right)}
$$

Where: $\overline{F_{1}}=$ First generation mean, $\overline{P_{1}}=$ Mean of the lower parent, $\overline{P_{2}}=$ Mean of the higher parent, and $M P=$ Mid parent value $=1 / 2 \overline{\left(P_{1}\right.}+\overline{\left.P_{2}\right)}$. The-absence of dominance 
was assumed when the difference between the parents was significant and $F_{1}-M P$ was not significant. Complete dominance was assumed when potence ratio equaled to or did not significantly differ from \pm 1.0 . Meanwhile, partial dominance was considered when potence ratio was between +1.0 and -1.0 , but was not equal to zero. Over dominance (Heterosis) was assumed when potence ratio exceeded \pm 1.0 .

Heterosis was calculated on better parent basis using the following formula:

$$
\text { Better-parent heterosis }=\frac{\overline{\mathrm{F}_{1}-\overline{\mathrm{BP}}}}{\overline{\mathrm{BP}}} \times 100 \quad \text { (Sinha and Khanna, 1975) }
$$

Where: $\bar{F}_{1}=$ Mean of the first hybrid generation and $\overline{B P}=$ Mean of the better parent.

The minimum number of genes controlling the character in each cross was calculated using Wright formula as follows:

$$
N=\frac{0.25\left(0.75-h+h^{2}\right) D^{2}}{V_{F 2}-V_{F 1}}
$$

where:

$$
h=\frac{\overline{F_{1}}-\overline{P_{1}}}{\overline{P_{2}}-\overline{P_{1}}}
$$

$\mathrm{N}=$ The minimum number of genes controlling the character in each cross, $\mathrm{D}=$ The difference between the observed mean of female and male parents, $P_{1}, P_{2}$ and $F_{1}$ are means of the parents and $F_{1}$ populations, respectively, and $V_{F 1}$ and $V_{F 2}=$ Variances of the $F_{1}$ and $F_{2}$ populations, respectively.

Broad senses heritability (BSH) was calculated using the equation:

$$
\mathrm{BSH}=\frac{\mathrm{V}_{\mathrm{G}}}{\mathrm{V}_{\mathrm{P}}} \times 100 \quad \text { (Allard, 1960) }
$$

where: $V_{G}=$ Genetic variance which was calculated by subtracting the environmental variance $\left(V_{E}\right)$ from $\left(V_{P}\right), V_{P}=$ Phenotypic variance $=V_{F 2}$, and $V_{E}=$ Environmental variance which was calculated as the geometric mean of variances of the nonsegregating populations, i.e. parents and $\mathrm{F}_{1}$.

\section{RESULTS AND DISCUSSION}

\section{Plant length}

Data obtained regarding plant length of parental, $F_{1}, F_{1} r$ and $F_{2}$ populations of the crosses Master $\times$ Perfection 57, Master $\times$ Prism and Master $\times$ Twin are presented in Table 2. 
Table 2. Distribution, mean and variance of plant length $(\mathrm{cm})$ for the parental, $F_{1}, F_{1} r$ and $F_{2}$ populations of some garden pea crosses.

\begin{tabular}{|c|c|c|c|c|c|c|c|c|c|c|c|c|c|}
\hline \multirow{2}{*}{ Population } & \multicolumn{10}{|c|}{ Frequency of plant length $(\mathrm{cm})$ in class ${ }^{2}$} & \multirow{2}{*}{$\begin{array}{l}\text { Total No. } \\
\text { of plants }\end{array}$} & \multirow[t]{2}{*}{ Mean } & \multirow{2}{*}{$\begin{array}{c}\text { Variance } \\
\quad\left(\delta^{2}\right)\end{array}$} \\
\hline & 14 & 25 & 36 & 47 & 58 & 69 & 80 & 91 & 102 & 113 & & & \\
\hline $\begin{array}{l}\text { Master }\left(P_{1}\right) \\
\text { Perfection } 57\left(P_{2}\right) \\
F_{1} \\
F_{1} r \\
F_{2}\end{array}$ & 2 & 11 & 17 & $\begin{array}{c}M \\
1 \\
7 \\
3 \\
2 \\
30\end{array}$ & $\begin{array}{c}6 \\
4 \\
5 \\
26\end{array}$ & $\begin{array}{c}8 \\
14 \\
11 \\
29\end{array}$ & $\begin{array}{c}9 \\
5 \\
9 \\
35\end{array}$ & $\begin{array}{c}4 \\
1 \\
14\end{array}$ & $\begin{array}{c}2 \\
10\end{array}$ & 1 & $\begin{array}{c}30 \\
30 \\
30 \\
30 \\
182 \\
\end{array}$ & $\left.\begin{array}{l}31.97 \pm 1.12 \\
64.97 \pm 2.33 \\
70.10 \pm 2.26 \\
71.93 \pm 2.41 \\
62.05 \pm 1.62\end{array}\right\}^{N *}$ & $\begin{array}{r}37.413 \\
162.585 \\
153.128 \\
174.685 \\
476.202\end{array}$ \\
\hline $\begin{array}{l}\text { Master }\left(P_{1}\right) \\
\text { Prism }\left(P_{2}\right) \\
F_{1} \\
F_{1} r \\
F_{2}\end{array}$ & 5 & 22 & $\begin{array}{c}17 \\
8\end{array}$ & $\begin{array}{c}1 \\
15\end{array}$ & $\begin{array}{c}6 \\
2 \\
4 \\
26\end{array}$ & $\begin{array}{l}\text { Prism } \\
1 \\
7 \\
12 \\
26\end{array}$ & $\begin{array}{c} \\
14 \\
7 \\
15\end{array}$ & $\begin{array}{l}5 \\
3 \\
5\end{array}$ & $\begin{array}{l}2 \\
3 \\
1\end{array}$ & 1 & $\begin{array}{c}30 \\
30 \\
30 \\
30 \\
159\end{array}$ & 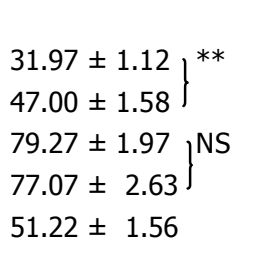 & $\begin{array}{r}37.413 \\
75.103 \\
116.271 \\
208.064 \\
388.730\end{array}$ \\
\hline $\begin{array}{l}\text { Master }\left(P_{1}\right) \\
\text { Twin }\left(P_{2}\right) \\
F_{1} \\
F_{1} r \\
F_{2}\end{array}$ & 2 & 12 & 17 & $\begin{array}{c}1 \\
18\end{array}$ & $\begin{array}{c}\text { laste } \\
13 \\
4 \\
4 \\
33\end{array}$ & $\begin{array}{l}\text { Twin } \\
5 \\
9 \\
10 \\
19\end{array}$ & $\begin{array}{c}5 \\
13 \\
10 \\
26\end{array}$ & $\begin{array}{l}4 \\
5 \\
9\end{array}$ & 3 & 1 & $\begin{array}{c}30 \\
30 \\
30 \\
30 \\
148\end{array}$ & $\left.\begin{array}{l}31.97 \pm 1.12 \\
60.93 \pm 2.04 \\
75.23 \pm 1.80 \\
74.13 \pm 2.09 \\
55.34 \pm 2.24\end{array}\right\}^{N S}$ & $\begin{array}{r}37.413 \\
124.616 \\
97.495 \\
131.292 \\
742.804\end{array}$ \\
\hline
\end{tabular}

${ }^{\mathrm{z}}$ Each class represents a range of $11 \mathrm{~cm}$ and class values indicated represent class centers.

${ }^{y}$ Pairs of means were either highly significantly $\left({ }^{* *}\right)$, significantly $\left(^{*}\right)$, or not significantly (NS) different from each other according to $(\mathrm{t})$ test. 
In all crosses, parents were distinctively different in plant length as shown in Table 2. Means of $F_{1}$ 's were higher than their respective parents. Mean of $F_{2}$ was higher than their respective parents in the cross Master $\times$ Prism, meanwhile, in the crosses Master $\times$ Perfection 57 and Master $\times$ Twin, means of $F_{2}$ 's were intermediate between their parents. $F_{2}$ plants of each cross were widely distributed between its two parents with transgressive segregations over the highest parent in all crosses.

No significant differences were observed between $F_{1}{ }^{\prime} s$ and their reciprocals for plant length in all crosses indicating absence of maternal effect. These results typically agree with those of Noser (2002) and Hamed (2005).

Quantitative genetic parameters obtained for plant length are presented in Table 3.

Table 3. Quantitative genetic parameters obtained for some characters in some garden pea crosses.

\begin{tabular}{|c|c|c|c|c|}
\hline Cross & $\begin{array}{c}\text { Potence ratio } \\
\text { (P) }\end{array}$ & $\begin{array}{l}\text { Better-parent } \\
\text { heterosis (\%) }\end{array}$ & $\begin{array}{c}\text { Minimum } \\
\text { number of genes } \\
\text { (MNG) }\end{array}$ & $\begin{array}{c}\text { Broad sense } \\
\text { heritability } \\
\text { (BSH\%) }\end{array}$ \\
\hline & \multicolumn{4}{|c|}{ Plant length } \\
\hline Master $\times$ Perfection 57 & 1.31 & 7.90 & 0.44 & 79.49 \\
\hline Master $\times$ Prism & 5.29 & 68.65 & 0.67 & 82.28 \\
\hline \multirow[t]{2}{*}{ Master $\times$ Twin } & 1.99 & 23.47 & 0.16 & 89.65 \\
\hline & \multicolumn{4}{|c|}{ Number of branches/plant } \\
\hline Master $\times$ Perfection 57 & 4.40 & 100.00 & 8.71 & 75.14 \\
\hline Master $\times$ Prism & 3.34 & 64.86 & 0.50 & 80.13 \\
\hline \multirow[t]{2}{*}{ Master $\times$ Twin } & 1.40 & 15.79 & 2.82 & 83.69 \\
\hline & \multicolumn{4}{|c|}{ Green pod yield/plant } \\
\hline Master $\times$ Perfection 57 & 6.70 & 160.48 & 2.35 & 79.44 \\
\hline \multirow[t]{2}{*}{ Master $\times$ Twin } & 4.10 & 118.29 & 1.10 & 90.81 \\
\hline & \multicolumn{4}{|c|}{ Number of pods/plant } \\
\hline Master $\times$ Perfection 57 & 4.90 & 130.37 & 3.97 & 79.18 \\
\hline Master $\times$ Prism & 5.59 & 148.18 & 5.70 & 77.30 \\
\hline \multirow[t]{2}{*}{ Master $\times$ Twin } & 2.58 & 65.94 & 2.61 & 79.91 \\
\hline & \multicolumn{4}{|c|}{ Pod weight } \\
\hline Master $\times$ Perfection 57 & -0.89 & -35.54 & 5.29 & 30.75 \\
\hline Master $\times$ Prism & -0.02 & -22.00 & 2.53 & 59.07 \\
\hline Master $\times$ Twin & 0.04 & -19.46 & 3.35 & 53.43 \\
\hline
\end{tabular}


Positive $\mathrm{P}$ value indicated over dominance of the high parent in the crosses Master $\times$ Prism and Master $\times$ Twin, and complete dominance of the high parent in the cross Master $\times$ Perfection 57. These results are in partially agreement with those of Noser (2002), Hamed (2005) and Sood and Kalia (2006), they found dominance towards high parent in some crosses of peas.

All the three studied crosses exhibited positive high-parent heterosis for plant length trait ranged from $7.90 \%$ to $68.65 \%$, with the cross Master $\times$ Prism which had the highest value. These results agree with those of Noser (2002) who found positive heterosis values for this character.

Plant length was found to be controlled by one pair of genes in all three studied crosses. These results are in partially agreement with the previous results which reported that this character was controlled by 1-5 genes (Noser, 2002) and 1-3 pairs of genes (Hamed, 2005).

Estimates of $\mathrm{BSH} \%$ for plant length were high, which ranges between $79.49 \%$ and $89.65 \%$ (Table 3). These results agree with estimates of Bora et al. (2009), Kumari et al. (2009) and Galal (2014), they found that it was high.

\section{Number of branches/plant}

Data obtained regarding number of branches/plant of parental, $F_{1}, F_{1} r$ and $F_{2}$ populations of the crosses Master $\times$ Perfection 57, Master $\times$ Prism and Master $\times$ Twin are presented in Table 4. 
Table 4. Distribution, mean and variance of branches number /plant for the parental, $F_{1}, F_{1} r$ and $F_{2}$ populations of some garden pea crosses.

\begin{tabular}{|c|c|c|c|c|c|c|c|c|c|c|}
\hline \multirow{2}{*}{ Population } & \multicolumn{7}{|c|}{ Frequency of branches number/plant in class ${ }^{2}$} & \multirow{2}{*}{$\begin{array}{l}\text { Total No. } \\
\text { of plants }\end{array}$} & \multirow{2}{*}{$\begin{array}{l}\text { Mean } \\
x \pm S_{x} \\
\end{array}$} & \multirow{2}{*}{$\begin{array}{c}\text { Variance } \\
\left(\delta^{2}\right)\end{array}$} \\
\hline & 1 & 2 & 3 & 4 & 5 & 6 & 7 & & & \\
\hline & \multicolumn{7}{|c|}{ Master $\times$ Perfection 57} & & & \\
\hline Master $\left(\mathrm{P}_{1}\right)$ & 27 & 3 & & & & & & 30 & $1.10 \pm 0.06{ }^{* *}$ & 0.093 \\
\hline Perfection $57\left(\mathrm{P}_{2}\right)$ & & 14 & 12 & 4 & & & & 30 & $2.67 \pm 0.13\}$ & 0.506 \\
\hline$F_{1}$ & & & 2 & 7 & 6 & 9 & 6 & 30 & $5.33 \pm 0.23, \mathrm{NS}$ & 1.540 \\
\hline $\mathrm{F}_{1} \mathrm{r}$ & & & 4 & 3 & 15 & 8 & & 30 & $4.90 \pm 0.18\}$ & 0.921 \\
\hline$F_{2}$ & 28 & 57 & 60 & 18 & 12 & 3 & 3 & 182 & $2.71 \pm 0.10$ & 1.677 \\
\hline \multicolumn{11}{|c|}{ Master $\times$ Prism } \\
\hline Master $\left(P_{1}\right)$ & 27 & 3 & & & & & & 30 & $1.10 \pm 0.06]^{* *}$ & 0.093 \\
\hline Prism $\left(P_{2}\right)$ & 1 & 16 & 11 & 2 & & & & 30 & $2.47 \pm 0.12\}$ & 0.464 \\
\hline$F_{1}$ & & & 7 & 15 & 7 & 1 & & 30 & $4.07 \pm 0.14, \mathrm{NS}$ & 0.616 \\
\hline $\mathrm{F}_{1} \mathrm{r}$ & & 4 & 8 & 8 & 8 & 2 & & 30 & $3.87 \pm 0.21\}$ & 1.361 \\
\hline$F_{2}$ & 20 & 43 & 54 & 26 & 12 & 3 & 1 & 159 & $2.47 \pm 0.10$ & 1.503 \\
\hline \multicolumn{11}{|c|}{ Master $\times$ Twin } \\
\hline Master $\left(\mathrm{P}_{1}\right)$ & 27 & 3 & & & & & & 30 & $1.10 \pm 0.06, * *$ & 0.093 \\
\hline Twin $\left(P_{2}\right)$ & & & & 4 & 20 & 6 & & 30 & $5.07 \pm 0.11\}$ & 0.340 \\
\hline$F_{1}$ & & & & 5 & 6 & 7 & 12 & 30 & $5.87 \pm 0.21, \mathrm{NS}$ & 1.292 \\
\hline $\mathrm{F}_{1} \mathrm{r}$ & & & & 1 & 8 & 18 & 3 & 30 & $5.77 \pm 0.12\}$ & 0.461 \\
\hline$F_{2}$ & 35 & 52 & 34 & 13 & 5 & 4 & 5 & 148 & $2.55 \pm 0.12$ & 2.113 \\
\hline
\end{tabular}

${ }^{2}$ Each class represents a range of a branch and class values indicated represent class centers.

y Pairs of means were either highly significantly $(* *)$, significantly $(*)$, or not significantly (NS) different from each other according to (t) test. 
In the all crosses, the parents were distinctively different in number of branches/plant trait. Means of $F_{1}$ 's were higher than the high parent in all the three crosses. Means of $F_{2}$ 's were higher than their respective parents in the crosses Master $\times$ Perfection 57 and Master $\times$ Prism, meanwhile, in the cross Master $\times$ Twin, mean of $F_{2}$ was intermediate between their parents. $F_{2}$ plants of each cross were widely distributed between its two parents with transgressive segregations over the highest parent in all studied crosses.

No significant differences were obtained between $F_{1}$ 's and their reciprocals for this trait in the studied crosses indicating absence of maternal effect. These results agree with those of Noser (2002) who reported that maternal effect was not observed in any of the studied crosses. This could be due to nature of self pollination in pea.

Quantitative genetic parameters obtained for number of branches/plant are presented in Table 3.

It is obvious from Table 4 that, high positive $P$ values indicating over dominance towards high parent were found in all the three crosses. These results partially agree with the results of Noser (2002) and Singh and Mishra (2002) who indicated the presence of over dominance and complete dominance towards the highest parent for this trait.

Data obtained on heterosis indicated that all evaluated crosses exhibited high positive heterosis values and ranged from $15.79 \%$ to $100.00 \%$. These results typically agree with the results of Noser (2002).

Minimum number of genes controlling number of branches/plant trait was estimated as a single pair in the cross Master $\times$ Prism, three pairs of genes in the cross Master $\times$ Twin, and nine pairs in the cross Master $\times$ Perfection 57 . These results partially agree with those obtained by Noser (2002) who estimated it as 1-3 pairs of genes.

Broad sense heritability (BSH) estimated for number of branches/plant was high and ranged from $75.14 \%$ to $83.69 \%$ as shown in Table 3 . These results agree with that obtained by Gupta et al. (2006) and Singh (2010).

\section{Green pod yield/plant}

Data obtained on green pod yield/plant trait of the parental, $F_{1}, F_{1} r$ and $F_{2}$ populations of the crosses Master $\times$ Perfection 57 and Master $\times$ Twin are presented in Table 5. 
Table 5. Distribution, mean and variance of green pod yield/plant $(g)$ for the parental, $F_{1}, F_{1} r$ and $F_{2}$ populations of some garden pea crosses.

\begin{tabular}{|c|c|c|c|c|c|c|c|c|c|c|c|c|c|c|}
\hline \multirow[b]{2}{*}{ Population } & \multicolumn{11}{|c|}{ Frequency of green yield/plant $(\mathrm{g})$ in class ${ }^{2}$} & \multirow[b]{2}{*}{$\begin{array}{l}\text { Total No. } \\
\text { of plants }\end{array}$} & Mean & \multirow[b]{2}{*}{$\begin{array}{c}\text { Variance } \\
\left(\delta^{2}\right)\end{array}$} \\
\hline & @i & $\stackrel{-1}{\sigma}$ & $\stackrel{\sim}{\mathscr{\sigma}}$ & $\begin{array}{l}\text { ma } \\
\stackrel{\sim}{\sim}\end{array}$ & $\begin{array}{l}\stackrel{\sigma}{\infty} \\
\stackrel{\leftrightarrow}{\sim}\end{array}$ & $\begin{array}{l}\text { ำ } \\
\text { هి }\end{array}$ & $\begin{array}{l}0 \\
\stackrel{N}{N}\end{array}$ & 芦 & $\begin{array}{l}\infty \\
\stackrel{\infty}{0} \\
\stackrel{0}{N}\end{array}$ & $\begin{array}{l}\text { a } \\
\infty \\
\infty \\
m\end{array}$ & 品 & & $X \pm S_{x}$ & \\
\hline & \multicolumn{11}{|c|}{ Master $\times$ Perfection 57} & & & \\
\hline Master $\left(P_{1}\right)$ & 28 & 1 & 1 & & & & & & & & & 30 & $33.21 \pm 2.36, * *$ & 166.998 \\
\hline Perfection $57\left(\mathrm{P}_{2}\right)$ & 5 & 11 & 10 & 4 & & & & & & & & 30 & $76.01 \pm 5.48$ & 901.313 \\
\hline $\mathrm{F}_{1}$ & & & & & 13 & 7 & 4 & 3 & 2 & 1 & & 30 & $197.99 \pm 8.53, \mathrm{NS}$ & 2180.442 \\
\hline$F_{1} r$ & & & & 2 & 1 & 7 & 10 & 8 & 2 & & & 30 & $219.39 \pm 7.28$ & 1588.253 \\
\hline $\mathrm{F}_{2}$ & 87 & 43 & 24 & 12 & 4 & 4 & 3 & 2 & & 3 & & 182 & $69.15 \pm 4.29$ & 3354.291 \\
\hline & & & & & & $2 \times T$ & & & & & & & & \\
\hline Master $\left(\mathrm{P}_{1}\right)$ & 28 & 1 & 1 & & & & & & & & & 30 & $33.21 \pm 2.36, * *$ & 166.998 \\
\hline Twin $\left(P_{2}\right)$ & & & 1 & 18 & 8 & 3 & & & & & & 30 & $140.21 \pm 4.27$ & 545.999 \\
\hline $\mathrm{F}_{1}$ & & & & & & & 3 & 4 & 7 & 4 & 12 & 30 & $306.06 \pm 8.23, \mathrm{NS}$ & 2032.395 \\
\hline$F_{1} r$ & & & & & & 1 & 1 & 2 & 9 & 8 & 9 & 30 & $307.13 \pm 7.46^{J}$ & 1668.790 \\
\hline$F_{2}$ & 46 & 31 & 26 & 13 & 12 & 3 & 4 & 5 & 2 & 4 & 2 & 148 & $98.54 \pm 6.47$ & 6205.573 \\
\hline
\end{tabular}

${ }^{\mathrm{z}}$ Each class represents a range of $32.1 \mathrm{~g}$ and class values indicated represent class centers.

y Pairs of means were either highly significantly $(* *)$, significantly $(*)$, or not significantly (NS) different from each other according to (t) test. 
It is notice from the data in Table 5 that, $F_{1}$ 's means were higher than the high parent in the two studied crosses, meanwhile, $F_{2}$ means were intermediate between their respective parents. $F_{2}$ plants of each cross were widely distributed between their parents with transgressive segregation over the highest parent in the two crosses.

No significant differences were observed between $F_{1}$ 's and their reciprocals for this character in the two crosses. These results partially agree with the findings of Noser (2002) who indicated that maternal effects were remarked in only 2 out of 6 crosses of garden peas.

Quantitative genetic parameters obtained for green pod yield/plant are presented in Table 3.

High positive $\mathrm{P}$ values (potence \%) indicating over dominance towards high yielding parent were found in the two studied crosses. These results were partially in agreement with that obtained by Sood and Kalia (2006), they found over dominance and partial dominance towards the high yielding parent in pea.

Positive high-parent heterosis values were estimated for the two studied crosses estimated as $118.29 \%$ and $160.48 \%$ in the crosses Master $\times$ Twin and Master $\times$ Perfection 57, respectively. These results agree with those obtained by Noser (2002).

Minimum number of genes controlling green pod yield/plant as shown in Table 3 was estimated as 2 pairs in the cross Master $\times$ Twin and 3 pairs in the cross Master $\times$ Perfection 57. These results disagree with previous results of Noser (2002) who estimated it as one pair of genes. These different results could be due to using different genotypes or different environmental conditions.

Estimates of broad sense heritability (BSH) for this character estimated as 79.44\% and $90.81 \%$ in the crosses Master $\times$ Perfection 57 and Master $\times$ Twin, respectively. These results were in agreement with that estimated by Bora et al. (2009), Choudhary et al. (2010), Singh (2010) and El-Dakkak et al. (2014), they estimated high $\mathrm{BSH}$ for this trait.

\section{Number of pods/plant}

Data obtained regarding number of pods/plant of the parental, $F_{1}, F_{1} r$ and $F_{2}$ populations of the crosses Master $\times$ Perfection 57, Master $\times$ Prism and Master $\times$ Twin are presented in Table 6. 
Table 6. Distribution, mean, and variance of pods number/plant for the parental, $F_{1}, F_{1} r$, and $F_{2}$ populations of some garden pea crosses.

\begin{tabular}{|c|c|c|c|c|c|c|c|c|c|c|c|c|c|}
\hline \multirow[b]{2}{*}{ Population } & \multicolumn{10}{|c|}{ Frequency of pods number/plant in class ${ }^{2}$} & \multirow{2}{*}{$\begin{array}{l}\text { Total No. } \\
\text { of plants }\end{array}$} & \multirow{2}{*}{$\begin{array}{l}\text { Mean } \\
X \pm S_{x}\end{array}$} & \multirow{2}{*}{$\begin{array}{l}\text { Variance } \\
\qquad\left(\delta^{2}\right)\end{array}$} \\
\hline & 6 & 17 & 28 & 39 & 50 & 61 & 72 & 83 & 94 & 105 & & & \\
\hline & \multicolumn{10}{|c|}{ Master $\times$ Perfection 57} & & & \\
\hline Master $\left(P_{1}\right)$ & 26 & 4 & & & & & & & & & 30 & $7.47 \pm 0.69\}^{* *}$ & 14.464 \\
\hline Perfection $57\left(P_{2}\right)$ & & 18 & 9 & 3 & & & & & & & 30 & $22.50 \pm 1.37\}$ & 56.328 \\
\hline $\mathrm{F}_{1}$ & & & & 14 & 6 & 4 & 4 & 1 & 1 & & 30 & $51.83 \pm 2.84, \mathrm{NS}$ & 242.695 \\
\hline $\mathrm{F}_{1} \mathrm{r}$ & & & 5 & 9 & 8 & 4 & 3 & 1 & & & 30 & $47.80 \pm 2.71\}$ & 220.303 \\
\hline $\mathrm{F}_{2}$ & 62 & 52 & 28 & 23 & 7 & 6 & 3 & 1 & & & 182 & $21.71 \pm 1.24$ & 279.819 \\
\hline \multicolumn{14}{|c|}{ Master $\times$ Prism } \\
\hline Master $\left(P_{1}\right)$ & 26 & 4 & & & & & & & & & 30 & $7.47 \pm 0.69\}^{* *}$ & 14.464 \\
\hline Prism $\left(P_{2}\right)$ & & 22 & 5 & 3 & & & & & & & 30 & $21.03 \pm 1.34$ & 54.102 \\
\hline$F_{1}$ & & & & 13 & 6 & 5 & 4 & 2 & & & 30 & $52.20 \pm 2.66\}$ NS & 211.959 \\
\hline $\mathrm{F}_{1} \mathrm{r}$ & & & & 16 & 5 & 3 & 2 & 2 & & 2 & 30 & $52.57 \pm 3.60$ & 389.564 \\
\hline $\mathrm{F}_{2}$ & 60 & 44 & 23 & 18 & 10 & 3 & & 1 & & & 159 & $20.23 \pm 1.23$ & 242.085 \\
\hline \multicolumn{14}{|c|}{ Master $\times$ Twin } \\
\hline Master $\left(\mathrm{P}_{1}\right)$ & 26 & 4 & & & & & & & & & 30 & $7.47 \pm 0.69\}^{* *}$ & 14.464 \\
\hline Twin $\left(P_{2}\right)$ & & & 1 & 13 & 13 & 3 & & & & & 30 & $45.60 \pm 1.45^{\}}$ & 63.421 \\
\hline$F_{1}$ & & & & & 2 & 5 & 12 & 5 & 4 & 2 & 30 & $75.67 \pm 2.60\}$ NS & 203.057 \\
\hline $\mathrm{F}_{1} \mathrm{r}$ & & & & 2 & 1 & 6 & 9 & 5 & 4 & 3 & 30 & $74.93 \pm 3.21\}$ & 308.202 \\
\hline $\mathrm{F}_{2}$ & 56 & 41 & 28 & 10 & 5 & 5 & 1 & 1 & 1 & & 148 & $20.34 \pm 1.39$ & 284.241 \\
\hline
\end{tabular}

${ }^{z}$ Each class represents a range of 11 pods and class values indicated represent class centers.

${ }^{y}$ Pairs of means were either highly significantly $\left({ }^{* *}\right)$, significantly $\left(^{*}\right)$, or not significantly (NS) different from each other according to (t) test. 
In the all crosses, the parents were distinctively different in number of pods/plant. Means of $F_{1}$ 's were higher than the high parent, meanwhile, means of $F_{2}$ 's were intermediate between their parents in the all three crosses. $F_{2}$ plants of each cross were widely distributed between its two parents with transgressive segregations over the highest parent.

No significant differences were obtained between $F_{1}$ 's and their reciprocals for this trait in the studied crosses indicating absence of maternal effect. These results partially agree with those of Noser (2002) who reported that maternal effect was not observed in any of the studied crosses. This could be due to nature of self pollination in peas.

Quantitative genetic parameters obtained for pods number/plant are presented in Table 3.

High positive $\mathrm{P}$ values indicating over dominance towards high parent were found in the all studied crosses. These results typically agree with the results of Sood and Kalia (2006).

Data obtained on heterosis as shown in Table 3 indicated that, all the evaluated crosses exhibited high positive heterosis values and ranged from $65.94 \%$ to $148.18 \%$. These results typically agree with the results of Noser (2002).

Minimum number of genes controlling number of pods/plant trait was estimated as three pairs in the cross Master $\times$ Twin, four pairs of genes in the cross Master $\times$ Perfection 57 and six pairs in the cross Master $\times$ Prism. These results were similar with those obtained by Hamed (2005) who estimated it as 1-7 pairs of genes.

Broad sense heritability (BSH) estimated for number of pods/plant was high and ranged from $77.30 \%$ to $79.91 \%$. These results indicating good scope for selection on number of pods/plant trait. These results agree with that obtained by Noser (2002), Hamed (2005), Zayed et al. (2005), Kumari et al. (2009), Choudhary et al. (2010), Singh et al. (2012), El-Dakkak et al. (2014) and Galal (2014). Therefore, selection programme based on this character would be more effective in improving yield of garden peas.

\section{Pod weight}

Data obtained on pod weight of parental, $F_{1}, F_{1} r$ and $F_{2}$ populations of the crosses Master $\times$ Perfection 57, Master $\times$ Prism and Master $\times$ Twin are presented in Table 7. 
Table 7. Distribution, mean and variance of pod weight $(g)$ for the parental, $F_{1}, F_{1} r$ and $F_{2}$ populations of some garden pea crosses.

\begin{tabular}{|c|c|c|c|c|c|c|c|c|c|c|c|c|c|}
\hline \multirow[b]{2}{*}{ Population } & \multicolumn{10}{|c|}{ Frequency of pod weight $(\mathrm{g})$ in class ${ }^{2}$} & \multirow{2}{*}{$\begin{array}{l}\text { Total No. } \\
\text { of plants }\end{array}$} & \multirow{2}{*}{$\begin{array}{l}\text { Mean } \\
\mathrm{X} \pm \mathrm{Sx}_{\mathrm{x}} \\
\end{array}$} & \multirow{2}{*}{$\begin{array}{c}\text { Variance } \\
\left(\delta^{2}\right)\end{array}$} \\
\hline & 1.3 & 2.2 & 3.1 & 4.0 & 4.9 & 5.8 & 6.7 & 7.6 & 8.5 & 9.4 & & & \\
\hline & \multicolumn{10}{|c|}{ Master $\times$ Perfection 57} & & & \\
\hline Master $\left(P_{1}\right)$ & & & & & 3 & 4 & 8 & 9 & 4 & 2 & 30 & $7.09 \pm 0.22\}^{* *}$ & 1.491 \\
\hline Perfection $57\left(\mathrm{P}_{2}\right)$ & & & 9 & 8 & 6 & 4 & 3 & & & & 30 & $4.42 \pm 0.22\}$ & 1.438 \\
\hline $\mathrm{F}_{1}$ & & & 6 & 7 & 9 & 8 & & & & & 30 & $4.57 \pm 0.18$ jNS & 0.977 \\
\hline $\mathrm{F}_{1} \mathrm{r}$ & & & 5 & 10 & 11 & 3 & 1 & & & & 30 & $4.45 \pm 0.17$ & 0.824 \\
\hline \multirow[t]{2}{*}{$F_{2}$} & 6 & 22 & 46 & 50 & 27 & 23 & 6 & 1 & & 1 & 182 & $3.97 \pm 0.10$ & 1.847 \\
\hline & \multicolumn{10}{|c|}{ Master $\times$ Prism } & & & \\
\hline Master $\left(P_{1}\right)$ & & & & & 3 & 4 & 8 & 9 & 4 & 2 & 30 & $7.09 \pm 0.22\}^{* *}$ & 1.491 \\
\hline Prism $\left(P_{2}\right)$ & & & 9 & 13 & 6 & 2 & & & & & 30 & $4.03 \pm 0.15^{\prime}$ & 0.642 \\
\hline$F_{1}$ & & & & 5 & 7 & 12 & 4 & 2 & & & 30 & $5.53 \pm 0.18 \jmath^{\mathrm{NS}}$ & 1.014 \\
\hline $\mathrm{F}_{1} \mathrm{r}$ & & & 5 & 5 & 5 & 5 & 6 & 4 & & & 30 & $5.32 \pm 0.28$ & 2.331 \\
\hline \multirow[t]{2}{*}{$F_{2}$} & 2 & 7 & 14 & 29 & 27 & 40 & 24 & 13 & 2 & 1 & 159 & $5.21 \pm 0.12$ & 1.555 \\
\hline & \multicolumn{10}{|c|}{ Master $\times$ Twin } & & & \\
\hline Master $\left(\mathrm{P}_{1}\right)$ & & & & & 3 & 4 & 8 & 9 & 4 & 2 & 30 & $7.09 \pm 0.22\}^{* *}$ & 1.491 \\
\hline Twin $\left(P_{2}\right)$ & & & 7 & 10 & 12 & 1 & & & & & 30 & $4.21 \pm 0.14$ & 0.597 \\
\hline$F_{1}$ & & & & 4 & 10 & 6 & 5 & 5 & & & 30 & $5.71 \pm 0.22 j^{N S}$ & 1.416 \\
\hline $\mathrm{F}_{1} \mathrm{r}$ & & & 2 & 2 & 8 & 13 & 3 & 1 & 1 & & 30 & $5.50 \pm 0.21\}$ & 1.303 \\
\hline $\mathrm{F}_{2}$ & & 1 & 5 & 12 & 24 & 33 & 31 & 26 & 10 & 6 & 148 & $6.23 \pm 0.13$ & 2.319 \\
\hline
\end{tabular}

z Each class represents a range of $0.9 \mathrm{~g}$ and class values indicated represent class centers.

${ }^{y}$ Pairs of means were either highly significantly $\left({ }^{* *}\right)$, significantly $\left(^{*}\right)$, or not significantly (NS) different from each other according to (t) test. 
In the all crosses, parents were distinctively different in pod weight trait. $F_{1}$ and $F_{2}$ means were intermediate between their respective parents except in the cross Master $\times$ Perfection 57 where its $F_{2}$ mean was lower than the low parent.

No significant differences were observed between $F_{1}$ 's and their reciprocals for this character in the all studied crosses indicating no maternal effect. These results agree with those of Hamed (2005).

Quantitative genetic parameters obtained for pod weight are presented in Table 3.

Different types of dominance were observed for this character. Positive $\mathrm{P}$ values (potence \%) were estimated indicating partial dominance towards the highest pod weight in the cross Master $\times$ Twin, however, negative $P$ values were observed indicating complete and partial dominance towards the lowest parent in the crosses Master $\times$ Perfection 57 and Master $\times$ Prism, respectively. These results partially agree with the results of Hamed (2005) who found partial dominance of the lowest parent for this character.

Negative heterosis values for pod weight were estimated for the all studied crosses ranged from $-35.54 \%$ to $-19.46 \%$. These results agree with the results of Hamed (2005) who found negative heterosis values for this trait.

Minimum number of genes controlling pod weight trait was estimated as three pairs in the cross Master $\times$ Prism, four pairs of genes in the cross Master $\times$ Twin and six pairs in the cross Master $\times$ Perfection 57 . These results were in agreement with the results of Hamed (2005) who estimated number of genes controlling this character as 3-5 pairs and confirm the polygenic inheritance of this character.

Estimates of broad sense heritability (BSH) were low to moderate and ranged from $30.75 \%$ to $59.07 \%$. These results confirm the interaction between environmental conditions and genetic constituents for this trait. These results disagree with that estimated by Bora et al. (2009) who estimated high BSH for this trait. Meanwhile, Gupta et al. (2006) and Galal (2014) estimated it as $74.65 \%$ and $75.0 \%$ to $80.0 \%$, respectively. On the contrary, Hamed (2005) found low BSH being $17.6 \%$ to $22.6 \%$ for this trait.

\section{CONCLUSION}

It's clear from the previous results that there are some traits, viz, plant length and green pod yield/plant are controlled by one to few numbers of genes and had moderate to high heritability, so the selection for these traits is preferred in the early generations. On the other hand, number of branches/plant and pod weight traits had polygenic effect and its low to moderate heritability, so the selection for these traits is suggested to be done in the late generations. 


\section{REFERENCES}

1. Allard, W. R. 1960. Principles of Plant Breeding. John Wiley \& Sons, Inc. 473 p.

2. Bora, L., V. K. Sharma, H. C. Raturi and S. K. Maurya. 2009. Studies on hybrid breeding and genetic variability in vegetable pea under high hilly condition of Uttarakhand. Annals of Horticulture 2 (2): 171-176.

3. Burton, G. W. 1951. Quantitative inheritance in pearl millet, Pennisetum glaucum. Agron. J. 43: 409-417.

4. Choudhary, H., M. K. Verma and A. A. Sofi. 2010. Genetic variability, heritability and genetic advance for yield components in garden pea. Pantnagar J. Res. 8: (2): 195-197. http://scialert.net

5. El-Dakkak, A. A. A., G. A. Zayed and M. A. H. Abd El-Hady. 2014. Improving productivity and earliness for pea by selection under sohag conditions. Egypt. J. Appl. Sci. 29 (11): 523-533.

6. Galal, R. M. 2014. Genetic analysis of pea yield and its components by diallel crossing. Egypt. J. Plant Breed. 18 (4): 799-811.

7. Gupta, A. J., Y. V. Singh and T. S. Verma. 2006. Genetic variability and heritability in garden pea (Pisum sativum L.). Indian J. Hort. 63 (3): 332-334.

8. Hamed, A. A. 2005. Genetic Studies on Powdery Mildew Resistance and Some Economic Characters in Some Pea Cultivars. Ph. D. Thesis, Fac. Agric., Cairo Univ., Egypt, 97 p.

9. Kumari, N., J. P. Srivastava and B. Singh. 2009. Heritability and genetic advance in vegetable pea (Pisum sativum L.). Annals of Hort. 2 (2): 224-225.

10. Noser, M. A (2002). Genetic Study on Some Economic Characters of Peas. Ph. D. Thesis, Fac. Agric., Cairo Univ., Egypt, 78 p.

11. Singh, D. and V. K. Mishra. 2002. Genetics of yield and yield components in pea (Pisum sativum L.). Legume Res. 25 (3): 219-221.

12. Singh, K. P. (2010). Selection criteria for improving yield and its components in table pea (Pisum sativum). Current Adv. Agric. Sci. 2 (1): 22-24. http://scialert.net

13. Singh, M., S. Malik, M. Kumar, K. V. Singh, S. Kumar, P. Dev and V. Kumar. 2012. Studies of variability, heritability and genetic advance in field pea (Pisum sativum L.). Prog. Agric. 12 (1): 219-222. http://www.indian journal.com 
14. Sinha, S. K. and R. Khanna. 1975. Physiological, biochemical and genetic basis of heterosis. Adv. Agron. 27: 123-174.

15. Smith, H. H. (1952). Fixing Transgressive Vigur in Nicotiana rustica. Iowa State College Press, Ames. Iowa. p. 161-174.

16. Sood, M. and P. Kalia. 2006. Gene action of yield-related traits in garden pea (Pisum sativum Linn.). SABRAO J. Breed. Genet. 38 (1): 1-17. http:// www.indianjournal.com

17. Zayed, G. A., F. A. Helal and S. T. Farag. 2005. The genetic performance of some continuously variable characteristics of pea under different locations. Annals of Agric. Sci., Moshtohor 43 (1): 349-358. 


\section{دراسات ور اثيه على بعض الصفات الكمية فى البسلة 1 -ور اثثة الصفات الخضرية و المحصول ومكوناتة}

\section{أثرف عبدالله حامد أحمد حلى حسين عصام محمد السيا على خليل}

$$
\text { أقسام بحوث الخضر - معهز بحوث البساتين - مركز البحوث الزراعية }
$$

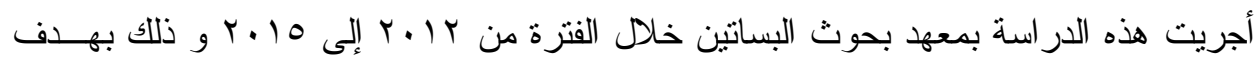

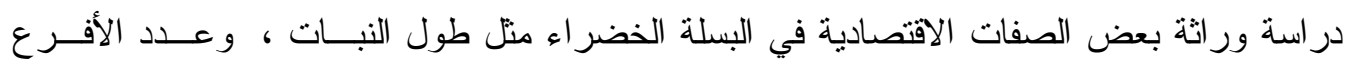

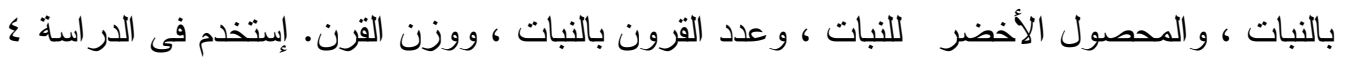

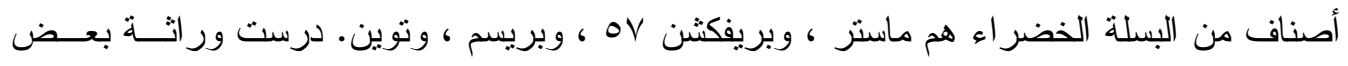

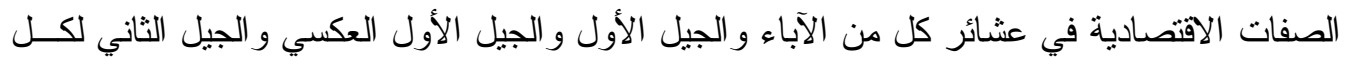

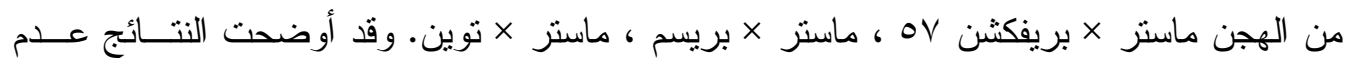

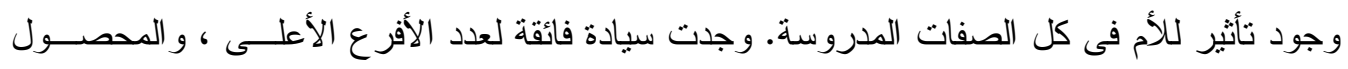

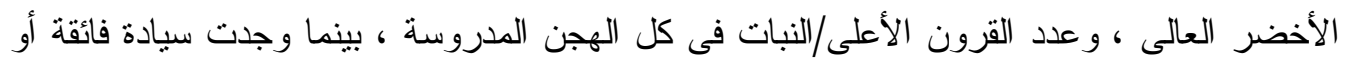

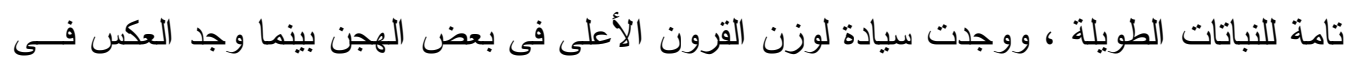

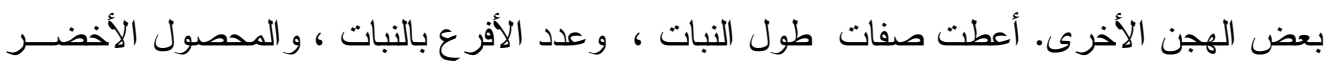

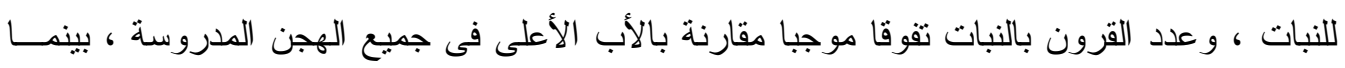

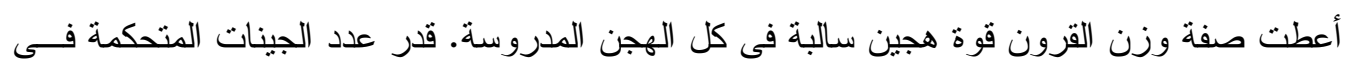

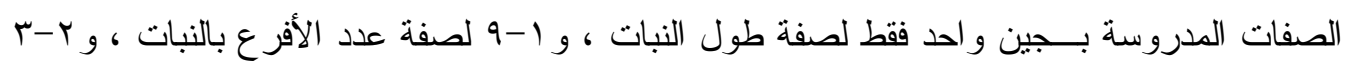
لصفة المحصول الأخضر ، و r-7 لصفتى عدد القرون بالنبات ووزن القرن. قدرت درجة التوريث

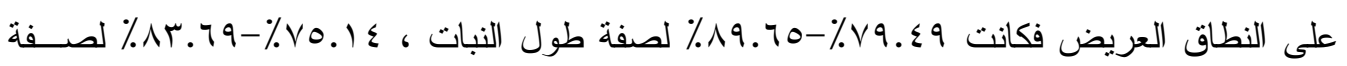

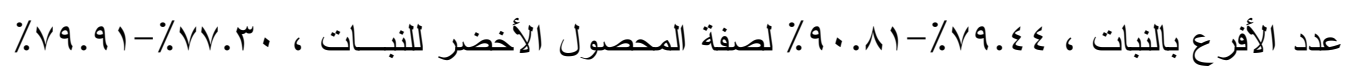

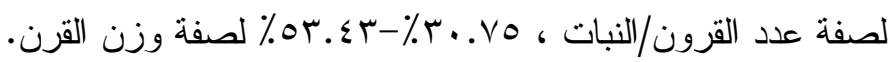
ومن البيانات السابقة يتضح أن هناك بعض الصفات التى يتحكم فيها عدد قليل مــن الجينـات التهات

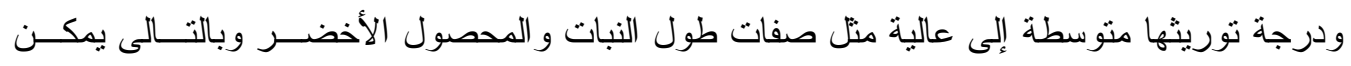

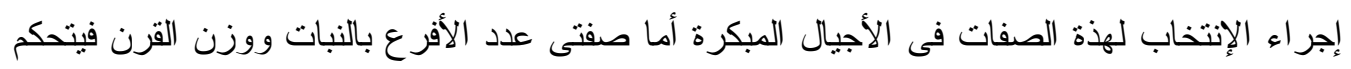

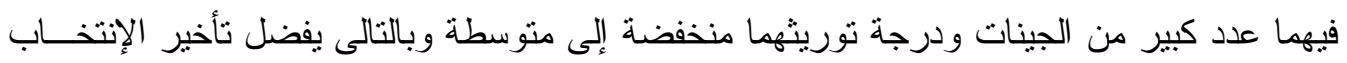
لهما للأجيال المتأخرة. 